\title{
Benthic Diatom Based Indices for Water Quality Assessment in Two Subtropical Streams
}

\author{
Xiang Tan ${ }^{1,2 *}$, Quanfa Zhang ${ }^{1}$, Michele A. Burford ${ }^{2}$, Fran Sheldon ${ }^{2}$ and Stuart E. Bunn ${ }^{2 *}$ \\ ${ }^{1}$ Key Laboratory of Aquatic Botany and Watershed Ecology, Wuhan Botanical Garden, the Chinese Academy of Sciences, \\ Wuhan, China, ${ }^{2}$ Australian Rivers Institute, Griffith University, Nathan, QLD, Australia
}

\section{OPEN ACCESS}

Edited by:

Hongyue Dang,

Xiamen University, China

Reviewed by:

Tatenda Dalu,

Rhodes University, South Africa

Irma-Lidia Szigyártó,

Sapientia Hungarian University of

Transylvania, Romania

*Correspondence:

Xiang Tan

xtan@wbgcas.cn

Stuart E. Bunn

s.bunn@griffith.edu.au

Specialty section: This article was submitted to

Aquatic Microbiology,

a section of the journal

Frontiers in Microbiology

Received: 14 April 2016 Accepted: 23 March 2017

Published: 07 April 2017

Citation:

Tan X, Zhang Q, Burford MA, Sheldon F and Bunn SE (2017) Benthic Diatom Based Indices for Water Quality Assessment in Two

Subtropical Streams.

Front. Microbiol. 8:601. doi: 10.3389/fmicb.2017.00601
Benthic diatoms have been universally used as indicators to assess water quality in lotic ecosystems. However, most diatom-based indices developed in Europe have not been widely used or tested in other continents such as Asia or Oceania. This study compared the performance of 14 widely-applied diatom indices in assessing ecological conditions in subtropical streams in South East Queensland (SEQ) in Australia and in the upper Han River in China. Most water quality variables in the upper Han River including dissolved organic carbon (DOC), total nitrogen (TN), and soluble reactive phosphorus (SRP) had strong relationships with at least one diatom index, with the exception of IDAP (Index Diatom Artois-Picardie), and TDI (Trophic Diatom Index). However, in SEQ, most of the environmental variables including DOC, ammonia nitrogen $\left(\mathrm{NH}_{4}-\mathrm{N}\right)$, TN, SRP, and electrical conductivity (EC) showed no significant relationships with diatom indices, and the DI-CH (Swiss Diatom Index) and WAT (Watanabe's Index) were unrelated to any of the variables examined. Only $\mathrm{pH}$ and nitrite or nitrate nitrogen $(\mathrm{NO}-\mathrm{N})$ were significant predictors of several diatom indices in SEQ, especially TID (Rott trophic index). In the upper Han River, much of the spatial variation in most diatom indices was explained by proximate determinants alone, including EC, DOC, dissolved oxygen (DO) or SRP, or a combination of ultimate (canopy, forest) and proximate factors $\left(R^{2}\right.$ in most models> 0.75). Most diatom indices performed as predicted in the upper Han River where nutrient and organic matter pollution was relatively high, and variation in $\mathrm{pH}$ low. However, the indices performed poorly in SEQ where the water quality gradient was low and instead most responded to spatial variation in $\mathrm{pH}$. This finding serves as a caution to the application of diatom indices in river basins that fall outside of the range of water quality values of the systems in which they originally developed.

Keywords: benthic algae, biological monitoring, community, diatom index, microbial, periphyton

\section{INTRODUCTION}

River ecosystems are under threat from various human activities across the globe leading to considerable changes in sediment delivery and flow patterns, declining water quality and loss of biodiversity (Dudgeon et al., 2006; Vörösmarty et al., 2010). Many streams are heavily impacted by land use change for agriculture and urban development (Allan, 2004) and some regions are under increasing pressure from rapid development (e.g., Weihoefer and Pan, 2006; Bunn et al., 2007). For example, human activities including agriculture and urban areas increasement resulted 
in alterations in watershed hydrology and sediment delivery, water quality deterioration in South East Queensland (Bunn et al., 2007). The major anthropogenic disturbances in Oregon Coast Range which is under increasing pressure associated with forest management practices and probably lead to declining status of stream biota such as salmonid fish (Weihoefer and Pan, 2006). With increasing degradation of freshwater ecosystems worldwide, there is a growing demand for effective approaches to ecosystem condition monitoring and evaluation, and bioassessments have been implemented in many countries.

Diatoms have been recognized as good indicators of land use change and water quality (Chessman et al., 2007; Chessman and Townsend, 2010; Lavoie et al., 2014; Stevenson, 2014). They represent an important component of freshwater ecosystems and respond quickly to environmental change. Several diatom indices have been implemented around the world. Examples include IPS (CEMAGREF, 1982), Trophic Diatom Index (TDI, Kelly and Whitton, 1995) and the Diatom Biological Index (IBD, Coste et al., 2009), which are based on a weighting average equation. There are also multimetric indices including the Biotic Integrity Index, which uses diatom community structural metrics based on relative abundance (Wang et al., 2005). Diatom indices developed in Europe have been confirmed for successful application in other temperate regions, however, there is little information regarding their suitability for assessing water quality in subtropical or tropical zones (Taylor et al., 2007).

There have been few studies on developing specific diatom indices for ecological health assessment in aquatic ecosystems in Australia and China (Chessman et al., 2007; Tan et al., 2013, 2014a, 2015). Our aim was to compare the effectiveness of diatom based indices used worldwide in subtropical streams in these two contrasting regions. Specifically, our aims were to: (1) determine the response of benthic diatom-based indices to proximate (e.g., flow velocity and nutrients) and ultimate environmental factors (e.g., land use and canopy cover in riparian zone); and (2) compare the robustness of the diatom indices in subtropical rivers in detecting environmental gradients between these two different geographic regions, i.e., whether they respond to stressors in the same ways.

\section{METHODS}

\section{Study Area}

The South East Queensland (SEQ) region with an area of 22,672 $\mathrm{km}^{2}$ is located in the subtropical climate zone and is the fastest developing area in Australia (Figure 1A; Abal et al., 2005). The region covers 15 major catchments including the upper Brisbane River, Lockyer Creek, and the Bremer, Logan, and Albert Rivers, which drain into Moreton Bay and the Pacific Ocean. The most dominant land use in the upper catchments is cattle grazing (Kerr et al., 2011). The other area of study, the Han River, is one of the first order tributaries of the Yangtze River (Changjiang) with a length of $1,577 \mathrm{~km}$. The upper Han River basin is defined as a watershed upstream of the Danjiangkou Reservoir (Figure 1B). The drainage area is $95,200 \mathrm{~km}^{2}$ with a length of $925 \mathrm{~km}$ for the mainstream of the upper Han River. Agricultural land accounts for about $15 \%$ of total land area.
Further information on the studied watersheds can be found in Tan et al. (2014a).

In SEQ subtropical streams the average TN concentration was about $1.0 \mathrm{mg} \mathrm{L}^{-1}$ (Haase and Nolte, 2008), which is considerably lower than that reported in some subtropical rivers in China ( $\mathrm{Li}$ et al., 2009; Tan et al., 2014a). In the upper Han River, nitrate nitrogen $\left(\mathrm{NO}_{3}-\mathrm{N}\right)$ varied from 0.2 to $15.3 \mathrm{mg} \mathrm{L}^{-1}$ with an average of $1.6 \mathrm{mg} \mathrm{L}^{-1} ; \mathrm{NH}_{4}-\mathrm{N}$ varied from 0.04 to $6.99 \mathrm{mg} \mathrm{L}^{-1}$ with an average $0.3 \mathrm{mg} \mathrm{L}^{-1}$ ( $\mathrm{Li}$ et al., 2009). In SEQ, about half of the $48,000 \mathrm{~km}$ of streams have degraded riparian zones (Bunn et al., 2010), though the percentage of dense riparian forest cover upstream of our sites ranged from 0 to $51 \%$ with an average of $12 \%$ (Tan, 2015). In contrast, the average of the remaining riparian zone vegetation cover was only $2 \%$ in the upper Han River except for that along some headwater creeks (Tan et al., 2014b).

\section{Physical and Chemical Parameters}

Water samples were taken from the 34 sites in SEQ in October 2011 and 23 sites in the upper Han River in April 2010 (both in spring) (Figure 1). Temperature $(t), \mathrm{EC}, \mathrm{DO}, \mathrm{pH}$, and turbidity were measured in situ using a Hydrolab Quanta Multiparameter meter. The velocity of flowing waters was detected using a current velocity meter (Model 2100, Swoffer Instruments, INC). Triplicate samples of the surface water at each site were collected and filtered using cellulose nitrate membrane filters (Whatman, $0.45 \mu \mathrm{m}$ pore size) for the analysis of total dissolved nutrient such as dissolved nitrogen (TDN), SRP, $\mathrm{NH}_{4}-\mathrm{N}$, nitrite or nitrate nitrogen $\left(\mathrm{NO}_{\mathrm{X}}-\mathrm{N}\right)$, and DOC by standard methods. Triplicate water samples were also collected for TN and total phosphorus (TP) analysis. Samples for analysis of dissolved nutrients were stored on ice in a cooler, and then frozen before analysis. Samples for $\mathrm{SRP}, \mathrm{NH}_{4}-\mathrm{N}$, and $\mathrm{NO}_{\mathrm{X}}-\mathrm{N}$ concentrations were analyzed with colorimetric assays using a Discrete Chemistry Analyser (SmartChem200, Westco Scientific Instruments Inc., Brookfield). The samples for total nutrients were digested in the laboratory using a simultaneous persulfate digestion method (Hosomi and Sudo, 1986) and were then analyzed colorimetrically using a flow injection analyser (LACHAT 8000QC). DOC and TDN were measured using a TOC/TN analyser, which was equipped with different modules for measuring TOC and TN (Shimadzu Corporation).

\section{Epilithic Diatom Sampling and Identification}

Epilithic diatoms were sampled by randomly selecting 5 cobbles within riffles of the sampling reach. An area with a diameter of $40 \mathrm{~mm}$ from each rock was scraped using a toothbrush and combined into 1 composite sample of $100 \mathrm{ml}$ per site. Two composite samples for algae identification were conducted at each site. Samples for diatom identification and enumeration were preserved with formaldehyde with a final concentration of formaldehyde of $4 \%$ in the samples.

For diatom slide preparation, samples were rinsed with deionized water to remove the formaldehyde and then digested with sulfuric acid $\left(\mathrm{H}_{2} \mathrm{SO}_{4}\right)$ followed by nitric acid $\left(\mathrm{HNO}_{3}\right)$. Samples were rinsed repeatedly with deionized water until the 

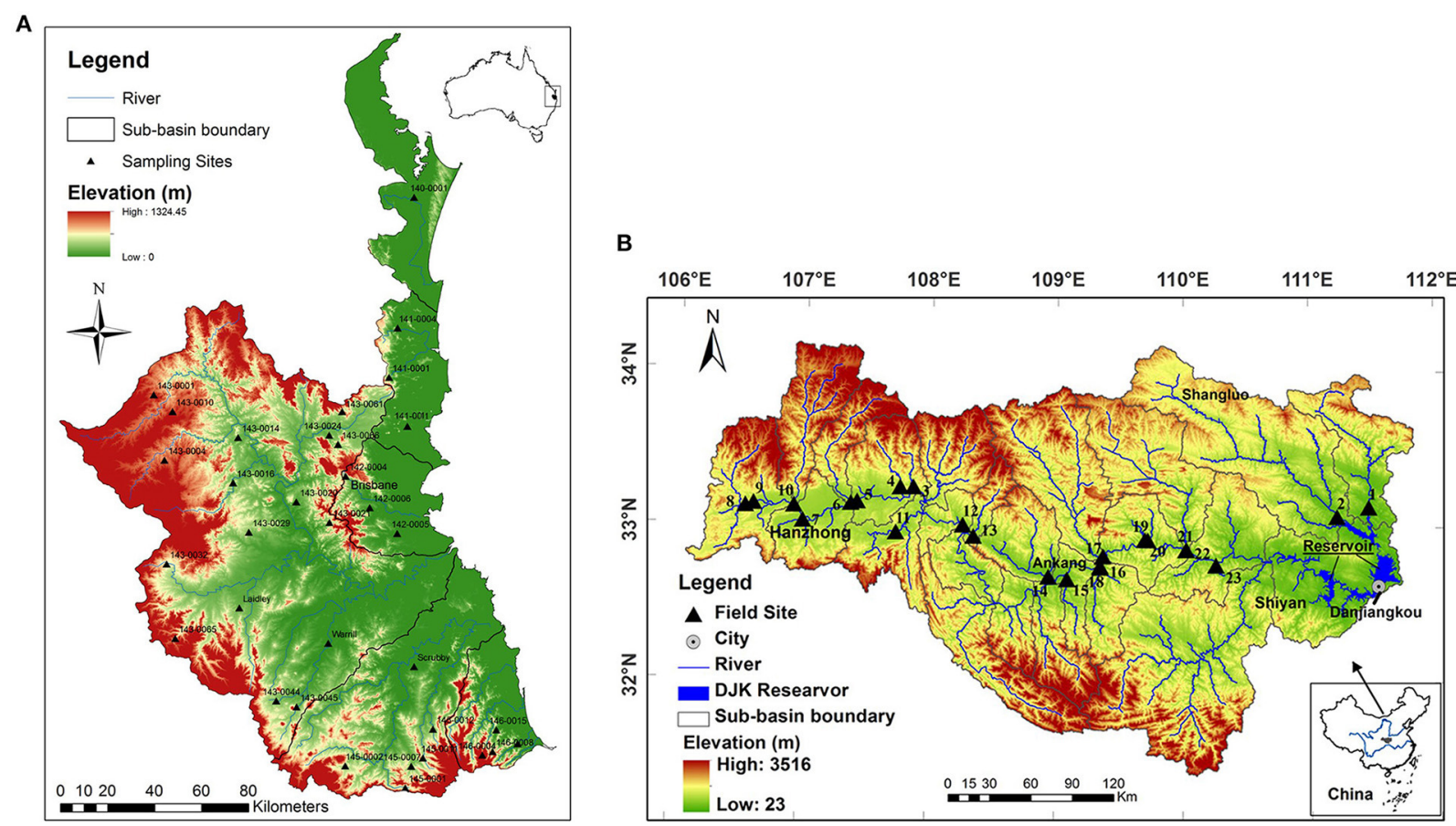

FIGURE 1 | The location of sampling sites in streams in South East Queensland (A) and in the upper Han River basin (B).

pH was approximately neutral and then mounted with Naphrax (Weihoefer and Pan, 2006). Benthic diatoms were mounted with Naphrax $^{\mathrm{TM}}$ and were identified at $1,000 \times$ magnification (Weihoefer and Pan, 2006; Tan et al., 2013). A minimum of 400 valves was counted per slide at $1,000 \times$ magnification. The methods for determinations of the algal taxonomy have been described by Tan et al. (2013).

\section{Land Use and Canopy Cover Percentage Analysis}

To estimate land use and canopy cover in SEQ, Landsat TM imagery was obtained from the work undertaken by Peterson et al. (2011). The Statewide Landcover And Trees Study (SLATS) Foliage Projective Cover data was used for the classification of forest (Armston et al., 2009). The urban data are from the National Environmental Stream Attributes (https://www.ga.gov. au/products/servlet/controller?event=GEOCAT_DETAILS\& catno=73045). Land cover types such as urban, mid-dense forest and dense forest were quantified using ArcGIS 10.1 Desktop GIS software.

Land cover classes in the upper Han River were categorized into five major classes, i.e., vegetation (forest, shrub), agriculture, urban, water surface and bare lands. The sampling site coordinates were used as the outlet point for each watershed and each land cover class was displayed as a percentage in its respective total subcatchment (Weihoefer and Pan, 2006). Land use percentage in the upper Han River was quantified using Landsat-7 ETM $^{+}$(2012) with supervised classification algorithms with ArcGIS 10.0 and ERDAS IMAGING 9.2 software.
In both regions, images of the riparian canopy were taken at $50-100 \mathrm{~cm}$ above the water surface at the spot where the samples were collected using a Nikon digital camera and fish-eye lens. Digital images were then analyzed for canopy cover percentage using Gap Light Analyser (GLA), Version 2.0.

\section{Data Analysis}

Fourteen diatom based indices (Table 1, Tan et al., 2013), which have been widely applied for assessment of ecological conditions, were calculated using OMNIDIA 7 software V 4.2 (Lecointe et al., 2003). Initially, the relationships between the diatom based indices and measured environmental factors (ultimate and proximate) in each study area were explored using Pearson's correlations. As there were multiple comparisons, the significance was Bonferroni-corrected and only assumed where $p<0.01$. For each diatom index, stepwise multiple regression was then used to explore which combination of ultimate and proximate variables best explained the observed variation in the diatom index (Tan et al., 2013). All statistical analyses were performed using IBM SPSS statistics for windows (IBM Corp, Version 21.0. Armonk, NY: IBM Corp.).

\section{RESULTS}

\section{The Epilithic Algae Assemblage Composition}

In SEQ, the Bacillariophyta (diatoms) comprised $86.4 \%$ of the total taxa. There were a total of 198 Bacillariophyta species from 48 genera (Appendix 1). The genera Nitzschia, Navicula, and 
TABLE 1 | Diatom based indices and the acronyms used in this study (from Tan et al., 2013, all the references in the Table can be found in Tan et al., 2013).

\begin{tabular}{ll}
\hline Abbreviation & Diatom indices \\
\hline CEE & $\begin{array}{l}\text { Commission for Economical Community metric (Descy and } \\
\text { Coste, 1991) }\end{array}$ \\
DESCY(or ID) & Descy's pollution metric (Descy, 1979) \\
DI-CH & Swiss Diatom index (Lecointe et al., 2003) \\
EPID & Diatom-based eutrophication/pollution index (Dell'Uomo, 1996) \\
IBD & Biological Diatom index (Prygiel and Coste, 2000) \\
IDAP & Index Diatom artois-picardie (Prygiel et al., 1996; Lecointe \\
IDP & et al., 2003) \\
IPS & Pampean diatom index (Gómez and Licursi, 2001) \\
SHE & Specific pollution sensitivity Index (CEMAGREF, 1982) \\
SID & Schiefele and Schreiner's Index (Schiefele and Schreiner, 1991) \\
SLAD & ROTT saprobic index (Rott et al., 1997) \\
TDI & Sládeček's index (Sládeček, 1986) \\
TID & Trophic Diatom index (Kelly et al., 1995) \\
WAT & ROTT trophic index (Rott, 1999) \\
\hline & Watanabe's Index (Watanabe et al., 1986; Lecointe et al., 2003) \\
\hline
\end{tabular}

Gomphonema accounted for the most species with 38, 30, and 15 species, respectively.

In the upper Han River, the Bacillariophyta comprised about 90\% of the total taxa. The genera Achnanthidium, Fragilaria, and Cymbella were the most common genera with an average abundance of 35,24 , and $19 \%$ in epilithic communities, respectively. The number of taxa found (132 taxa from 33 genera of Bacillariophyta) (Appendix 2) was smaller than the 198 taxa from SEQ streams. Of the taxa in both catchments, Gomphonema minutum Agardh was the most common species, with a relative abundance of $12.5 \%$ in SEQ and 5.9\% in the upper Han River (Table 2). For further details about the epilithic diatom community composition, see Tan (2015).

\section{The Diatom Indices}

In SEQ, five diatom indices (CEE, DESCY, SID, SLAD, and TID) were significantly correlated with one or more environmental variables in the streams after Bonferroni correction (Table 3). Only canopy cover in the riparian zone and $\mathrm{pH}$ were significantly correlated with these indices. Among the 14 diatom index regression models (stepwise regression models), $70 \%$ of the observed variation in TID was explained by $\mathrm{pH}$ together with $\mathrm{NO}_{\mathrm{X}}-\mathrm{N}$ (Table 4). Some indices appeared to be responsive to ultimate factors such as the percentage of canopy vegetation cover in the riparian zone or upstream urban areas in the catchment. Variation in DESCY could be explained by the percentage of canopy cover in riparian zones; IBD was predicted by the percentage of urban area upstream in the catchment and IDAP by the percentage of forest cover.

In $\mathrm{uHR}$, most diatom indices had a strong correlation with one or more environmental variables, once Bonferroni corrected (Table 3). Except for temperature, $\mathrm{NO}_{3}-\mathrm{N}$ and turbidity, most water quality variables had strong relationships with at least one diatom index. A larger proportion of the observed variation in diatom indices was explained by environmental variables in the uHR compared with SEQ (Table 4). A significant portion of the observed variation in DESCY, DI-CH, EPI-D, IPS, and SID was explained by DOC, while variation in SHE and WAT were primarily explained by nitrogen concentration $\left(\mathrm{NO}_{3}-\mathrm{N}\right)$ (Table 4). Much of the observed variation in CEE, DI-CH, IPS, SHE, SID, SLAD, and WAT was explained by proximate determinants such as EC, DOC, DO, and SRP or by the combination of ultimate factors (i.e., canopy \% in riparian zone, forest $\%$ in the upstream) and proximate factors $\left(R^{2}>0.75\right)$. Land use upstream (forest or urban land cover) explained a significant proportion of the variation in three indices, CEE, SHE, and SID.

\section{DISCUSSION}

These results indicate that the diatom indices can be used as bioindicators of anthropogenic activities such as land use change, riparian zone degradation, and nutrient loading, however, their performance varied markedly between the two regions. There is general agreement that a good indicator will consistently detect change across space and time, but will be sufficiently sensitive to respond to changes in environmental factors (Cottingham and Carpenter, 1998; Nelson et al., 2013). The sensitivity of diatoms has been confirmed by the significant relationships between measured proximate environmental variables and diatom indices in this study (Table 3). Furthermore, the influence of ultimate factors such as land use and land cover on diatom indices was also evident. Other studies have shown that not only the spatial pattern of epilithic diatom assemblages but also the diatom indices respond to ultimate factors such as land use change (Leland and Porter, 2000; Pan et al., 2004). The reason may be that the effects of human activities on landscape, such as conversion of forest to agricultural area, or degradation of riparian zone canopy have directly or indirectly influenced water quality parameters in waterways (Leland and Porter, 2000; Leland et al., 2001; Snyder et al., 2002; Potapova and Charles, 2003; Carr et al., 2005).

Diatom indices have been developed because they have been found to respond to water quality gradients including nutrients (Kelly et al., 1995), ion concentrations (Prygiel et al., 2002), and organic loading (e.g., WAT, Watanabe et al., 1986). However, this study has showed that few indices respond in the way as they were predicted and indeed some responded to other environmental factors.

Why do the diatom indices respond to disturbance differently in two basins? There are several possible explanations. First, the prediction of diatom indices may depend heavily on the similarity of species composition in the area of interest and the taxa used for developing each index. For example, IDP (Pampean Diatom Index) was not correlated with any environmental parameters in SEQ probably because only 33 taxa (16\% of the total 203 identified species) were included in the taxa list (210 species) in the IDP calculation (Gómez and Licursi, 2001). In SEQ, WAT did not perform well because only a small proportion of taxa were included in the taxa list (548 diatom taxa) used in the WAT calculation (Watanabe et al., 1986). Also, IDAP cannot be 
TABLE 2 | The dominant species and their relative abundance (RA) in South East Queensland (SEQ) and the upper Han River (uHR) (relative abundance refers only to the Bacillariophyta; site number is 34 in SEQ and 23 in $u H R$ ).

\begin{tabular}{|c|c|c|c|}
\hline \multicolumn{2}{|l|}{ SEQ } & \multicolumn{2}{|l|}{$u H R$} \\
\hline Dominant species & RA (\%) & Dominant species & RA (\%) \\
\hline Rhoicosphenia abbreviata (Agardh) Lange-Bertalot & 15.60 & Achnanthidium pyrenaicum (Hustedt) Kobayasi & 17.10 \\
\hline Gomphonema minutum (Agardh) Agardh & 12.50 & Achnanthidium subatomus (Hustedt) Lange-Bertalot & 12.50 \\
\hline Cocconeis placentula var.euglypta (Ehrenberg) Grunow & 9.60 & Achnanthidium saprophila (Kobayasi \& Mayama) Round \& Bukhtiyarova & 6.40 \\
\hline Achnanthidium minutissimum (Kützing) Czarnecki & 7.00 & Gomphonema minutum (Agardh) Agardh & 5.90 \\
\hline Gomphonema sp. & 6.20 & Melosira varians Agardh & 5.80 \\
\hline
\end{tabular}

explained by any environmental variables in the uHR, which is consistent with the findings in the same region in November 2007 (Tan et al., 2013). In SEQ, 70\% of variation in TID was explained by $\mathrm{pH}$ and to a lesser degree $\mathrm{NO}_{\mathrm{X}}-\mathrm{N}$. The TID (Rott trophic index) is predicted to respond to environmental variables which relate to trophic state including nitrogen levels (Rovira et al., 2012). The majority (>70\%) of species which were included in the development of the TID index were also found in our studies.

The IPS (Specific Pollution Sensitivity Index) has been regarded as one of the most precise indices to calibrate other indices because it incorporates approximately 2000 species, the largest among all diatom indices (Descy and Coste, 1991). More than $70 \%$ of the common species in the uHR could be found in the IPS list. Most of the variation (82\%) in the IPS index was explained by parameters such as EC, SRP concentration and urban area\% in the uHR, which is consistent with the finding that IPS responds to water quality parameters related to conductivity and eutrophication (Descy and Coste, 1991). These examples support the view that the performance of diatom-based indices in part depends on degree of overlap between the taxa list in the index development and those that occur in the sampled streams.

Another issue likely to affect the performance of diatom indices in different geographic regions is the range in water quality in the region where the diatom index was originally developed and the range in the regions where it is used. Among diatom communities, the relative importance of an environmental variable in accounting for variation depends on its range of variation in the data set (Potapova and Charles, 2002). The range of $\mathrm{PO}_{4}^{3-}$ in the original region where the IDP developed was from 0.46 to $6.92 \mathrm{mg} \mathrm{L}^{-1}$ (Gómez and Licursi, 2001). However, the range of SRP in SEQ varied from only 0.00 to $0.16 \mathrm{mg} \mathrm{L}^{-1}$ with an average of $0.03 \mathrm{mg} \mathrm{L}^{-1}$, while the concentration of TP varied from 0.01 to $0.18 \mathrm{mg} \mathrm{L}^{-1}$ with an average of $0.05 \mathrm{mg} \mathrm{L}^{-1}$. Similarly, in the uHR the range of SRP varied from 0.007 to $0.06 \mathrm{mg} \mathrm{L}^{-1}$ and the concentration of TP varied from 0.02 to $0.4 \mathrm{mg} \mathrm{L}^{-1}$ (Tan et al., 2013, 2014a,b). The average of TN concentration was $2.5 \mathrm{mg} \mathrm{L}^{-1}$ in rivers in Poland where IBD and IPS were tested (Szulc and Szulc, 2013). In comparison, the average of TN concentration in SEQ rivers was only $0.06 \mathrm{mg} \mathrm{L}^{-1}$, which was approximately one fortieth that of the rivers in Poland. Similarly, the average of SRP was $0.2 \mathrm{mg} \mathrm{L}^{-1}$ in Polish rivers (Szulc and Szulc, 2013) but only $0.03 \mathrm{mg} \mathrm{L}^{-1}$ in SEQ. Obviously, the range of nutrients in SEQ is different from the range in North-Central European freshwater systems where most indices have been developed.

It is not surprising that environmental parameters that can explain most of the variation of diatom indices such as IPS in SEQ are different from the parameters in the uHR. For example, IPS was correlated with parameters related to organic pollution, ionic strength, and eutrophication of water quality (Descy and Coste, 1991). It was found that IPS significantly correlated with nitrate in the Artois-Picardie water Basin in France (Prygiel and Coste, 1993). The environmental variables associated with the diatom indices probably differ across geographic regions because the limiting factors for reproduction and growth are different.

Finally, it is very interesting that, in contrast to many other streams/rivers in the world (Gomà et al., 2005; Kalyoncu et al., 2009; Tan et al., 2013), diatom indices in SEQ responded more strongly to $\mathrm{pH}$ than to nutrients. Although diatom indices are normally used to assess the trophic state of waters, diatoms are sensitive to $\mathrm{pH}$ and liable to respond if there is a large gradient in $\mathrm{pH}$ across a broad scale (Potapova and Charles, 2002). For example, CEE, DESCY IPS, and SLAD have been found to correlate with pH (Prygiel and Coste, 1993; Prygiel et al., 2002). The $\mathrm{pH}$ gradient in streams in SEQ was large, from 5.36 to 8.12 , but the nutrient gradient was small (Table 5). Compared with previous studies (Gomà et al., 2005; Kalyoncu et al., 2009), water conditions in SEQ are quite different from other regions in the world where these indices have been developed and tested. According to the literature, diatom indices have been explored in few rivers with the same combination of large $\mathrm{pH}$ gradient and low nutrients as in streams in SEQ. The streams in Argentina (Gómez and Licursi, 2001) where IDP index was developed had a similar $\mathrm{pH}$ gradient to that in SEQ but also had a high nutrient gradient.

\section{CONCLUSIONS}

This study has shown that diatom indices respond to ultimate environmental factors such as land use change and proximate factors including water quality across two subtropical basins. One diatom index (TID) in SEQ and 10 diatom indices in the upper Han River performed well (above $50 \%$ of the observed variation in the diatom indices was explained by environmental variables). More diatom indices performed well in the China 


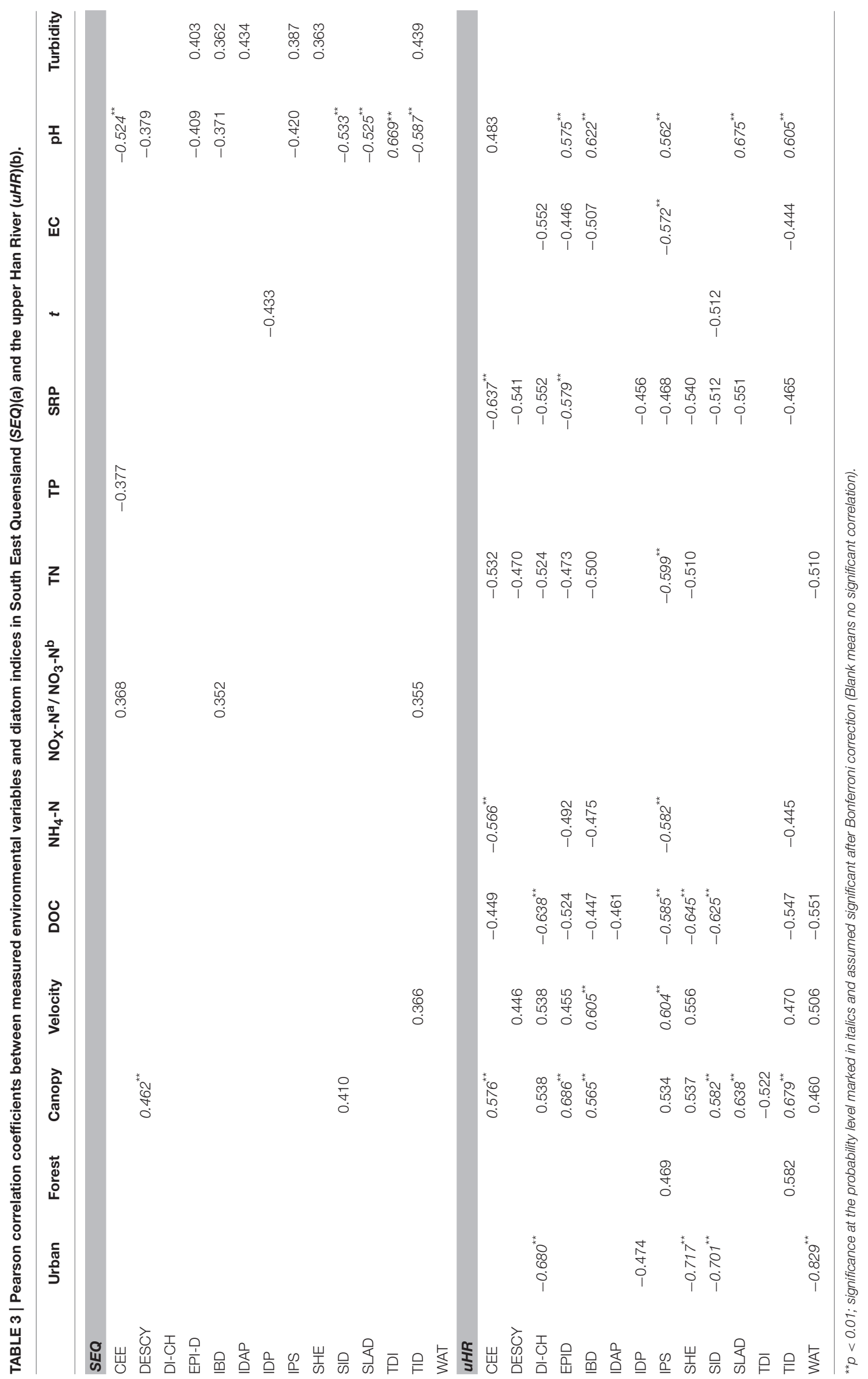




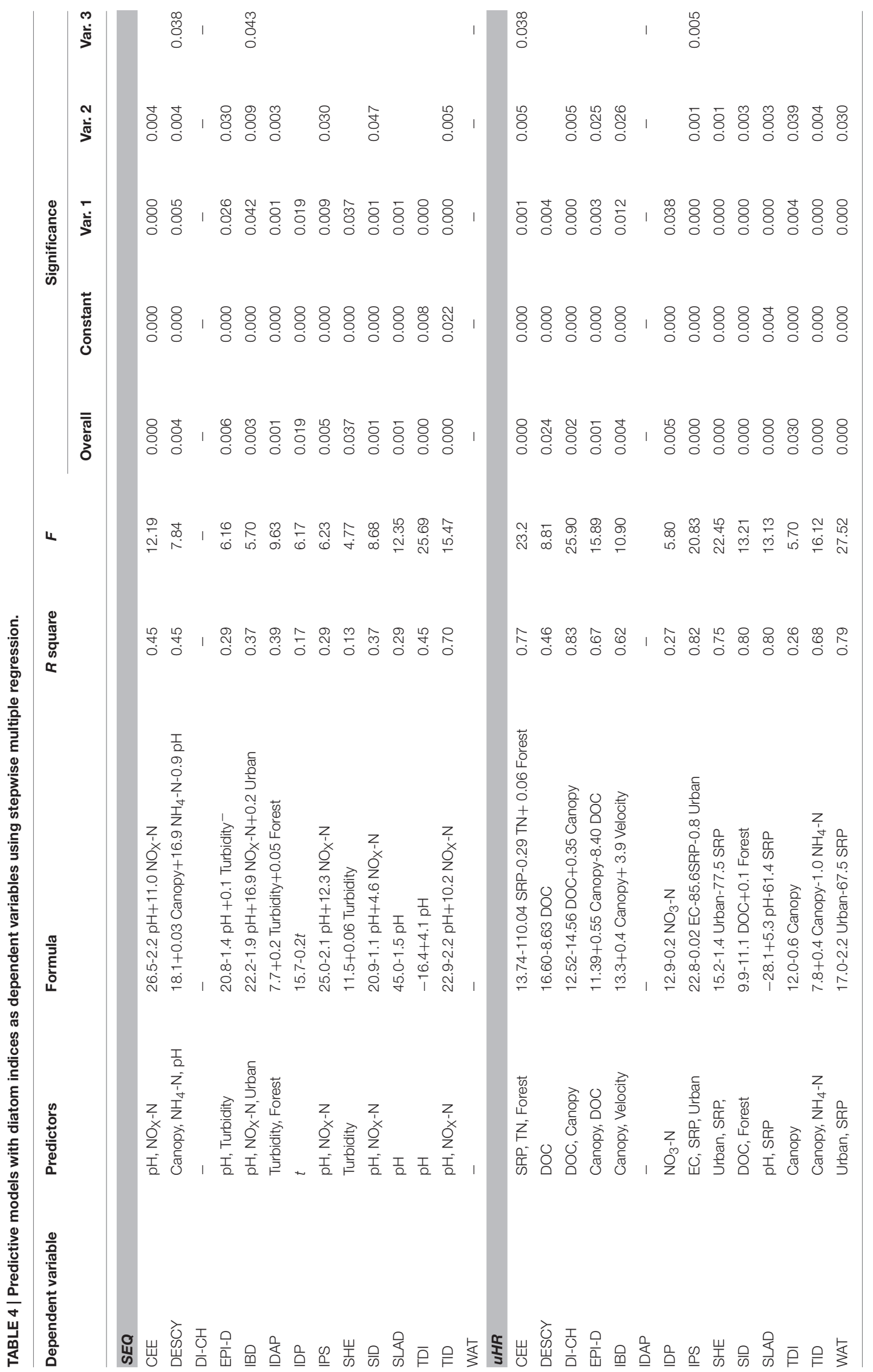


TABLE 5 | Summary of the nutrient and pH range where the diatom indices perform well in the world.

\begin{tabular}{|c|c|c|c|}
\hline Diatom index & $\mathrm{pH}$ range-small (range $\leq 2$ ) & $\mathrm{pH}$ range-medium $(<2$ range $<3$ ) & $\mathrm{pH}$ range-large (range $\geq 3$ ) \\
\hline $\begin{array}{l}\text { Nutrient range-small (TN: range } \leq 0.1 \mathrm{mg} \mathrm{L}^{-1} \text {; } \mathrm{TP} \text { or } \\
\left.\text { SRP: range } \leq 0.02 \mathrm{mg} \mathrm{L}^{-1}\right)\end{array}$ & $\begin{array}{l}\text { IBD in the River Loup in Alpes Maritimes, } \\
\text { France (Prygiel et al., 2002). }\end{array}$ & & $\begin{array}{l}14 \text { diatom indices in SEQ (this } \\
\text { study). }\end{array}$ \\
\hline $\begin{array}{l}\text { Nutrient range-medium }\left(\mathrm{TN}: 0.1 \mathrm{mg} \mathrm{L}^{-1}<\text { range }\right. \\
<5 \mathrm{mg} \mathrm{L}^{-1} \text {; TP or SRP: } 0.02 \mathrm{mg} \mathrm{L}^{-1}<\text { range }< \\
\left.0.2 \mathrm{mg} \mathrm{L}^{-1}\right)\end{array}$ & $\begin{array}{l}\text { EPI-D, IDAP, IPS in coastal streams in } \\
\text { the Gulf of Gdansk Region (Zgrundo and } \\
\text { Bogaczewicz-Adamczak, 2004); } \\
\text { CEE, IBD and IPS in the upper Segre } \\
\text { basin (La Cerdanya, Oriental Pyrenees) } \\
\text { (Gomà et al., 2005). }\end{array}$ & $\begin{array}{l}\text { EPI-D, TDI and IPS in waters in } \\
\text { wetlands of central Italy (Bella et al., } \\
\text { 2007). }\end{array}$ & \\
\hline $\begin{array}{l}\text { Nutrient range-large }\left(\mathrm{TN} \text { : range } \geq 5 \mathrm{mg} \mathrm{L}^{-1} \text {; TP or }\right. \\
\left.\text { SRP: range }>0.2 \mathrm{mg} \mathrm{L}^{-1}\right)\end{array}$ & $\begin{array}{l}\text { IPS and TDI in England and Scotland } \\
\text { (Kelly et al., 1995); } \\
\text { DI-CH in South Turkey (Kalyoncu et al., } \\
\text { 2009); } \\
\text { EPI-D, IBD and IPS in the upper Segre } \\
\text { basin (La Cerdanya, Oriental Pyrenees) } \\
\text { (Gomà et al., 2005); } \\
\text { EPI-D, IBD and WAT in the uHR, China } \\
\text { (Tan et al., 2013). }\end{array}$ & $\begin{array}{l}\text { EPI-D, TDI and IPS in waters in } \\
\text { wetlands of central Italy (Bella et al., } \\
\text { 2007). }\end{array}$ & $\begin{array}{l}\text { IDP inrivers and streams in } \\
\text { Argentina (Gómez and Licursi, } \\
\text { 2001). }\end{array}$ \\
\hline
\end{tabular}

streams than in the Australian streams because there was more overlap in the range of water quality variables between China and the regions where the indices were developed. There was also less of an overlap in diatom species between the original regions of the indices (Europe) and Australia compared with China. In the absence of a strong pollution gradient, diatom indices in SEQ responded strongly to natural variations in $\mathrm{pH}$.

\section{AUTHOR CONTRIBUTIONS}

XT, QZ, FS, and SB conceived and designed this study. XT performed the field trip, sample analysis and data analysis. XT drafted the original manuscript. MB provided comments. SB provided the very constructive suggestion and revision.

\section{REFERENCES}

Abal, E. G., Bunn, S. E., and Dennison, W. C. (eds.). (2005). Healthy Waterways Healthy Catchments: Making the Connection in South East Queensland, Australia. Brisbane, QLD: Moreton Bay Waterways and Catchments Partnership.

Allan, J. D. (2004). Landscapes and riverscapes: the influence of land use on stream ecosystems. Ann. Rev. Ecol. Evol. Syst. 35, 257-284. doi: 10.1146/annurev.ecolsys.35.120202.110122

Armston, J. D., Denham, R. J., Danaher, T. J., Scarth, P. F., and Moffiet, T. N. (2009). Prediction and validation of foliage projective cover from Landsat-5 TM and Landsat-7 ETM+ imagery. J. Appl. Remote Sens. 3, 033540-033528. doi: $10.1117 / 1.3216031$

Bella, V. D., Puccinelli, C., Marcheggiani, S., and Mancini, L. (2007). Benthic diatom communities and their relationship to water chemistry in wetlands of central Italy. Ann. Limnol. Int. J. Lim. 43, 89-99. doi: 10.1051/limn/2007021

Bunn, S. E., Abal, E. G., Greenfield, P. F., and Tarte, D. M. (2007). Making the connection between healthy waterways and healthy catchments:South East Queensland, Australia. Water Sci. Technol. Water Supply. 7, 93-100. doi: $10.2166 /$ ws.2007.044

\section{ACKNOWLEDGMENTS}

The research was supported by the National Natural Science Foundation of China (nos. 31200354, 311300101). I appreciate the considerable contribution of Dr. Doug Ward of Griffith University, Dr. Yulong Zhang of the University of North Carolina at Chapel Hill and Mr. Kenn Tews of Griffith University in land use analysis. The lead author also received postgraduate scholarship support from Griffith University.

\section{SUPPLEMENTARY MATERIAL}

The Supplementary Material for this article can be found online at: http://journal.frontiersin.org/article/10.3389/fmicb. 2017.00601/full\#supplementary-material

Bunn, S. E., Abal, E. G., Smith, M. J., Choy, S. C., Fellows, C. S., Harch, B. D., et al. (2010). Integration of science and monitoring of river ecosystem health to guide investments in catchment protection and rehabilitation. Freshw. Biol. 55, 223-240. doi: 10.1111/j.1365-2427.2009.02375.x

Carr, G. M., Chambers, P. A., and Morin, A. (2005). Periphyton, water quality, and land use at multiple spatial scales in Alberta rivers. Can. J. Fish. Aquat. Sci. 62, 1309-1319. doi: 10.1139/f05-044

CEMAGREF (1982). "Etude des méthodes biologiques d'appréciation quantitative de la qualité des eaux," in Bassin Rhône-Mediterrannée-Corse, eds Q. E. Rapport and A. F. Lyon (Lyon: CSIRO), 218.

Chessman, B. C., Bate, N., Gell, P. A., and Newall, P. (2007). A diatom species index for bioassessment of Australian rivers. Mar. Freshw. Res. 58, 542-557. doi: 10.1071/MF06220

Chessman, B. C., and Townsend, S. A. (2010). Differing effects of catchment land use on water chemistry explain contrasting behaviour of a diatom index in tropical northern an temperate southern Australia. Ecol. Indic. 10, 620-626. doi: 10.1016/j.ecolind.2009.10.006

Coste, M., Boutry, S., Tison-Rosebery, J., and Delmas, F. (2009). Improvements of the Biological Diatom Index (BDI): description andefficiency of the new version (BDI-2006). Ecol. Indic. 9, 621-650. doi: 10.1016/j.ecolind.2008.06.003 
Cottingham, K. L., and Carpenter, S. R. (1998). Population, community, and ecosystem variates as ecological indicators: phytoplankton responses to whole-lake enrichment. Ecol. Appl. 8, 508-530. doi: 10.1890/10510761(1998)008[0508:PCAEVA]2.0.CO;2

Dell'Uomo, A. (1996). Assessment of Water Quality of An Apennine River as a Pilot Study for Diatom-Based Monitoring of Italian Watercourses. Use of Algae for Monitoring Rivers II. Institut für Botanik, Universität Innsbruck, Innsbruck.

Descy, J. P. (1979). A new approach to water quality estimation using diatoms. Nova Hedwigia Beiheft. 64, 305-323.

Descy, J. P., and Coste, M. A. (1991). A test of methods for assessing water quality based on diatoms. Int. Assoc. Theor. Appl. Limnol. 24, 2112-2116.

Dudgeon, D., Arthington, A. H., Gessner, M. O., Kawabata, Z. I., Knowler, D. J., Leveque, C., et al. (2006). Freshwater biodiversity: importance, threats, status and conservation challenges. Biol. Rev. 81, 163-182. doi: $10.1017 /$ S1464793105006950

Gomà, J., Rimet, F., Cambra, J., Hoffmann, L., and Ector, L. (2005). Diatom communities and water quality assessment in Mountain Rivers of the upper Segre basin (La Cerdanya, Oriental Pyrenees). Hydrobiologia 551, 209-225. doi: $10.1007 /$ s10750-005-4462-1

Gómez, N., and Licursi, M. (2001). The Pampean Diatom Index (IDP) for assessment of rivers and streams in Argentina. Aquat. Ecol. 35, 163-181. doi: 10.1023/A:1011415209445

Haase, R., and Nolte, U. (2008). The invertebrate species index (ISI) for streams in southeast Queensland, Australia. Ecol. Indic. 8, 599-613. doi: 10.1016/j.ecolind.2007.08.005

Hosomi, M., and Sudo, R. (1986). Simultaneous determination of total nitrogen and total phosphorus in freshwater samples using persulfate digestion. Int. J. Environ. Stud. 27, 167-275. doi: 10.1080/00207238608710296

Kalyoncu, H., Çiçek, N. L., Akköz, C., and Yorulmaz, B. (2009). Comparative performance of diatom indices in aquatic pollution assessment. Afr. J. Agric. Res. 4, 1032-1040.

Kelly, M. G., Penny, J., and Whitton, B. A. (1995). Comparative performance of benthic diatom indices used to assess river water quality. Hydrobiologia 302, 169-188. doi: 10.1007/BF00032108

Kelly, M. G., and Whitton, B. A. (1995). The trophic diatom index: a new index for monitoring eutrophication in rivers. J. Appl. Phycol. 7, 433-444. doi: 10.1007/BF00003802

Kerr, J. G., Burford, M., Olley, J., and Udy, J. (2011). Phosphorus sorption in soils and sediments: implications for phosphate supply to a subtropical river in southeast Queensland, Australia. Biogeochemistry 102, 73-85. doi: 10.1007/s10533-010-9422-9

Lavoie, I., Campeau, S., Zugic-Drakulic, N., Winter, J. G., and Fortin, C. (2014). Using diatoms to monitor stream biological integrity in Eastern Canada: an overview of 10 years of index development and ongoing challenges. Sci. Total Environ. 475, 187-200. doi: 10.1016/j.scitotenv.2013.04.092

Lecointe, C., Coste, M., and Prygiel, J. (2003). Omnidia 3.2. Diatom Index Software Including Diatom Database with Taxonomic Names, References and Codes of 11645 Diatom Taxa.

Leland, H. V., Brown, L. R., and Mueller, D. K. (2001). Distribution of algae in the San Joaquin River, California, in relation to nutrient supply, salinity and other environmental factors. Freshw. Biol. 46, 1139-1167. doi: 10.1046/j.1365-2427.2001.00740.x

Leland, H. V., and Porter, S. D. (2000). Distribution of benthic algae in the upper Illinois River basin in relation to geology and land use. Freshw. Biol. 44, 279-301. doi: 10.1046/j.1365-2427.2000.00536.x

Li, S., Gu, S., Tan, X., and Zhang, Q. (2009). Water quality in the upper Han River basin, China: the impacts of land use/land cover in riparian buffer zone. J. Hazard. Mater. 165, 317-324. doi: 10.1016/j.jhazmat.2008.09.123

Nelson, C. E., Bennett, D. M., and Cardinale, B. J. (2013). Consistency and sensitivity of stream periphyton community structural and functional responses to nutrient enrichment. Ecol. Appl. 23, 159-173. doi: 10.1890/12-0295.1

Pan, Y., Herlihy, A., Kaufmann, P., Wigington, J., van Sickle, J., and Moser, T. (2004). Linkages among land-use, water quality, physical habitat conditions and lotic diatom assemblages: a multi-spatial scale assessment. Hydrobiologia 515, 59-73. doi: 10.1023/B:HYDR.0000027318.11417.e7

Peterson, E. E., Sheldon, F., Darnell, R., Bunn, S. E., and Harch, B. D. (2011). A comparison of spatially explicit landscape representation methods and their relationship to stream condition. Freshw. Biol. 56, 590-610. doi: 10.1111/j.1365-2427.2010.02507.x

Potapova, M. G., and Charles, D. F. (2003). Distribution of benthic diatoms in U. S. Rivers in relation to conductivity and ionic composition. Freshw. Biol. 48, 1311-1328. doi: 10.1046/j.1365-2427.2003.01080.x

Potapova, M. G., and Charles, F. D. (2002). Benthic diatoms in USA rivers: distributions along spatial and environmental gradients. J. Biogeograp. 29, 167-187. doi: 10.1046/j.1365-2699.2002.00668.x

Prygiel, J., Carpentier, P., Almeida, S., Coste, M., Druart, J., Ector, L., et al. (2002). Determination of the biological diatom index (IBD NF T 90354): results of an intercomparison exercise. J. Appl. Phycol. 14, 27-39. doi: 10.1023/A:1015277207328

Prygiel, J., and Coste, M. (1993). The assessment of water quality in the ArtoisPicardie water basin(France) by the use of diatom indices. Hydrobiologia 269/270, 343-349. doi: 10.1007/BF00028033

Prygiel, J., and Coste, M. (2000). Guide Méthodologique Pour la Mise en Oeuvre de l'Indice Biologique Diatomées NF T 90-354. Agences de l'Eau-CemagrefGroupement de Bordeaux. Agences de l'Eau.

Prygiel, J., Leveque, L., and Iserentant, R. (1996). Un nouvel indice diatomique pratique pour l'évaluation de la qualité des eaux en réseau de surveillance. J. Water Sci. 9, 97-113.

Rott, E. (ed.). (1999). Teil, 2: Trophieindikation Sowie Geochemische Präferenz; Taxonomische und Toxikologische Anmerkungen. Indikationslisten für Aufwuchsalgen in österreichischen Fliessgewässern, Wien.

Rott, E., Hofmann, G., Pall, K., Pfister, P., and Pipp, E. (1997). Teil, 1: Saprobielle Indikation. Indikationslisten für Aufwuchsalgen in österreichischen Fliessgewässern, Wien.

Rovira, L., Trobajo, R., and Ibáñez, C. (2012). The use of diatom assemblages as ecological indicators in highly stratified estuaries and evaluation of existing diatom indices. Mar. Pollut. Bull. 64, 500-511. doi: 10.1016/j.marpolbul.2012.01.005

Schiefele, S., and Schreiner, C. (1991). "Use of diatoms for monitoring nutrient enrichment, acidification and impact of salt in rivers in Germany and Austria," in Use of Algae for Monitoring Rivers, eds B. A. Whitton, E. Rott, and G. Friedrich (Universität Innsbruck, Institut für Botanic), 103-110.

Sládeček, V. (1986). Diatoms as indicators of organic pollution. Clean Soil Air Water 14, 555-566.

Snyder, E. B., Robinson, C. T., Minshall, G. W., and Rushforth, S. R. (2002). Regional patterns in periphyton accrual and diatom assemblage structure in a heterogeneous nutrient landscape. Can. J. Fish. Aquat. Sci. 59, 564-577. doi: 10.1139/f02-021

Stevenson, J. (2014). Ecological assessments with algae: a review and synthesis. $J$. Phycol. 50, 437-461. doi: 10.1111/jpy.12189

Szulc, B., and Szulc, K. (2013). The use of the Biological Diatom Index (BDI) for the assessment of water quality in the Pilica River, Poland. Oceanol. Hydrobiol. Stud. 42, 188-194. doi: 10.2478/s13545-013-0073-Z

Tan, X. (2015). Environmental Influences on Benthic Algal Communities and Their Application for Biomonitoring of Australian and Chinese Rivers. Ph.D Dissertation. Griffith University, Brisbane.

Tan, X., Ma, P., Bunn, S. E., and Zhang, Q. (2015). Development of a benthic diatom index of biotic integrity (BD-IBI) for ecosystem health assessment of human dominant subtropical rivers, China. J. Environ. Manage. 151, 286-294. doi: 10.1016/j.jenvman.2014.12.048

Tan, X., Ma, P., Xia, X., and Zhang, Q. (2014a). Spatial pattern of benthic diatoms and water quality assessment using diatom indices in a subtropical river, China. Clean-Soil Air Water 42, 20-28. doi: 10.1002/clen.201200152

Tan, X., Sheldon, F., Bunn, S. E., and Zhang, Q. (2013). Using diatom indices for water quality assessment in a subtropical river, China. Environ. Sci. Pollut. Res. 20, 4164-4175. doi: 10.1007/s11356-012-1343-9

Tan, X., Xia, X., Zhao, Q., and Zhang, Q. (2014b). Temporal variations of benthic diatom community and its main influencing factors in a subtropical river, China. Environ. Sci. Pollut. Res. 21, 434-444. doi: 10.1007/s11356-0131898-0

Taylor, C. J., Prygiel, J., Vosloo, A., de la Rey, A. P., and van Rensburg, L. (2007). Can diatom-based pollution indices be used for biomonitoring in South Africa? A case study of the Crocodile West and Marico water management area. Hydrobiologia 592, 455-464. doi: 10.1007/s10750-0070788-1 
Vörösmarty, C. J., McIntyre, P. B., Gessner, M. O., Dudgeon, D., Prusevich, A., Green, P. A., et al. (2010). Global threats to human water security and river biodiversity. Nature 467, 555-561. doi: 10.1038/nature09440

Wang, Y., Stevenson, R. J., and Metzmeier, L. (2005). Development and evaluation of a diatom-based Index of biotic integrity for the Interior Plateau Ecoregion, USA. J. N. Am. Benthol. Soc. 24, 990-1008. doi: 10.1899/03-028.1

Watanabe, T., Asai, K., and Houki, A. (1986). Numerical estimation to organic pollution of flowing water by using epilithic diatom assemblageDiatom assemblage Index (DAIpo). Sci. Total Environ. 55, 209-218. doi: 10.1016/0048-9697(86)90180-4

Weihoefer, C. L., and Pan, Y. (2006). Diatom assemblages and their associations with environmental variables in Oregon Coast Range streams, USA. Hydrobiologia 561, 207-219. doi: 10.1007/s10750-005$1615-1$
Zgrundo, A., and Bogaczewicz-Adamczak, B. (2004). Applicability of diatom indices for monitoring water quality in coastal streams in the Gulf of Gdańsk Region, Northern Poland. Oceanol. Hydrobiol. Stud. XXXIII, 31-46.

Conflict of Interest Statement: The authors declare that the research was conducted in the absence of any commercial or financial relationships that could be construed as a potential conflict of interest.

Copyright $\odot 2017$ Tan, Zhang, Burford, Sheldon and Bunn. This is an open-access article distributed under the terms of the Creative Commons Attribution License (CC $B Y)$. The use, distribution or reproduction in other forums is permitted, provided the original author(s) or licensor are credited and that the original publication in this journal is cited, in accordance with accepted academic practice. No use, distribution or reproduction is permitted which does not comply with these terms. 